\title{
PERANAN ADVOKAT DALAM MEWUJUDKAN KEWENANGAN PENGADILAN AGAMA DALAM BIDANG KEWARISAN
}

\author{
Mohammad Ramli \\ STAI Miftahul Ulum Pamekasan \\ Email: madaniinsancemerlang@gmail.com
}

\begin{abstract}
In matters of inheritance between religious people, Islam has determined in the Law which establishes the authority of the Court. This authority has been approved in a limited way in the Religious Court Law. The problem that often occurs is that the advocate as the attorney of the plaintiff (the Client) does not follow these provisions and instead addresses the District Court on the basis of Unlawful Acts. In general, clients do not know about the endorsement. When this happens, the role of the advocate will be canceled by the role of the religious court and deciding the case of inheritance between Muslims (Islamic personaliatas)
\end{abstract}

Keywords: advocate, Religious Court, Inheritance

\section{Pendahuluan}

Lembaga peradilan dalam suatu negara merupakan hal yang sangat strategis dan menentukan, kerena lembaga peradilan bertindak untuk menyelesaikan sengketa yang terjadi di dalam masyarakat dan memberikan sanksi pada anggota masyarakat yang melakukan pelanggaran hukum sesuai dengan hukum yang telah ditentukan. Di Indonesia dalam rangka memperkuat prinsip kekuasaan lembaga peradilan yang merdeka dan mandiri dalam memerankan tugas dan fungsinya sebagaimana amanat Undang-Undang Dasar Negara Republik Indonesia 1945 kemudian dalam pelaksanaanya dibentuk Undang-Undang Nomor 48 Tahun 2009 tentang Kekuasaan Kehakiman. Di dalam Penjelasan Undang-Undang Nomor 48 Tahun 2009 tentang Kekuasaan Kehakiman dinyatakan bahwa, "terdapat tiga lingkungan peradilan yang disebut sebagai peradilan khusus yaitu lingkungan Peradilan Agama, Peradilan Militer dan Peradilan Tata Usaha Negara.

Peradilan Agama merupakan salah satu peradilan yang bersifat khusus, yang mempunyai kewenangan khusus yang ditujukan kepada umat Islam dengan ruang lingkup kewenangan yang khusus baik mengenai perkaranya maupun para pencari keadilannya (justiciabe)."1 Kompetensi absolut Peradilan Agama

\footnotetext{
1 Abdul Ghofur Anhori, Peradilan Agama di Indonesia Pasca UU No.3 Tahun 2006 (Sejarah, Kedudukan dan Kewenangan), UII Press, Yogyakarta, 2007, 1

Ulumuna: Jurnal Studi Keislaman

Vol.5 No.2 Desember 2019:

P-ISSN 2442-8566

E-ISSN 2685-9181
} 
dinyatakan dalam Pasal 49 Undang-Undang Nomor 7 Tahun 1989 yaitu bahwa Pengadilan Agama bertugas dan berwenang memeriksa, memutus dan menyelesaikan perkara-perkara di tingkat pertama antara orang-orang Islam di bidang (a) Perkawinan, (b) kewarisan, wasiat dan hibah yang dilakukan berdasarkan hukum Islam (c) wakaf dan shadaqah. Kewenangan ini diperluas pada bidang ekonomi syariah yaitu dengan disahkannya Undang-Undang Nomor 3 Tahun 2006. Bidang hukum kewarisan diatur dalam Pasal 49 ayat (3) yang menyatakan bahwa ruang lingkup hukum kewarisan yang menjadi kewenangan Pengadilan Agama adalah "penentuan siapa-siapa yang berhak menjadi ahli waris, penentuan mengenai harta peninggalan, penentuan bagian masing-masing ahli waris dan melaksanakan pembagian harta peninggalan tersebut."

Di Indonesia bidang hukum kewarisan masih berlaku pluralisme hukum, yaitu terdapat tiga sistem hukum yang berlaku secara berdampingan yaitu hukum waris Barat (selanjutnya disebut KUH Perdata), hukum waris adat dan hukum waris Islam. Demikian juga dalam hukum acara dalam perkara warisan di Indonesia hingga saat ini masih berlaku dualisme badan peradilan yaitu Pengadilan Negeri dan Pengadilan Agama. Dalam Undang-Undang Nomor 7 Tahun 1989 mengenal adanya pilihan hukum (selanjutnya disebut opsi hukum) dalam perkara waris.Hak opsi adalah hak untuk menentukan hukum apa yang akan dipergunakan untuk menyelesaikan suatu masalah. Opsi hukum tersebut memberikan konsekuensi terhadap pengadilan mana yang akan mengadili suatu perkara waris.

Landasan hukum positif penerapan hukum kewarisan Islam juga semakin kokoh sebagaimana dinyatakan dalam Penjelasan Umum UndangUndang Nomor 3 Tahun 2006 yang menganulir hak opsi di atas sehingga apabila pihak-pihak yang mengajukan perkara kewarisan beragama Islam maka secara otomatis akan menjadi kewenangan Pengadilan Agama dan dalam mengadili dan memutuskan perkara kewarisan tersebut akan mendasarkan pada hukum waris Islam. Hal ini berarti Pengadilan Negeri tidak berwenang lagi menerima dan mengadili perkara kewarisan antar orang yang beragama Islam.

Pendapat yang berbeda menyatakan ketidaksetujuannya dengan penghapusan opsi hukum kewenangan Pengadilan Negeri dalam perkara kewarisan antar orang Islam. Dalam hubungannya dengan kewenangan Pengadilan Agama dalam perkara kewarisan, profesi advokat sangatlah penting karena advokat adalah pihak yang menentukan arah dari perkara setelah tercapai kesepakatan dengan klien.

Dalam praktik terkadang advokat enggan atau malas untuk berperkara di Pengadilan Agama dalam perkara kewarisan. Hal ini nampak dari beberapa putusan Mahkamah Agung Republik Indonesia yang membatalkan putusan Pengadilan Negeri dan Pengadilan Tinggi karena dinilai telah membuat putusan 
yang bukan merupakan kompetensi Pengadilan. Rata-rata advokat mengaburkan perkara yang sebenarnya yaitu perkara pewarisan antar orang Islam yang sebenarnya merupakan kewenangan Pengadilan Agama, namun kemudian diajukan ke Pengadilan Negeri dengan perkara perbuatan melawan hukum, yang notabene memang merupakan kewenangan Pengadilan Negeri.

\section{Kewenangan Peradilan Agama Dalam Perkara Kewarisan}

Perubahan besar dalam kewenangan Pengadilan Agama dalam menangani perkara waris adalah pada 20 Maret 2006 yaitu dengan disahkannya Undang-Undang Nomor 3 Tahun 2006 tentang Perubahan Pertama Atas Undang-Undang Nomor 7 Tahun 1989 tentang Peradilan Agama. Salah satu perubahan yang mendasar dari Undang-Undang Nomor 3 Tahun 2006 tersebut adalah perluasan kewenangan Peradilan Agama.

Perluasan kewenangan Peradilan Agama tidak bisa lepas dari fakta bahwa mayoritas penduduk Indonesia yang beragama Islam sehingga menjadi faktor pendorong berkembangannya hukum Islam di Indonesia terutama dalam bidang muamalah. Di dalam Undang-Undang Peradilan Agama yang baru terdapat beberapa hal pokok yang mengalami perubahan, yaitu :

1. Pengadilan Agama berwenang memeriksa, memutus dan menyelesaikan perkara di tingkat pertama antara orang-orang yang beragama Islam di bidang perkawinan, waris, wasiat, hibah, wakaf, zakat, infaq, shadaqah dan ekonomi syariah. Dengan demikian terdapat perluasan kewenangan Pengadilan Agama dari sebelimnya khususnya dalam bidang ekonomi syariah. Penyelesaian sengketa tidak hanya dibatasi di bidang perbankan syariah melainkan juga di bidang ekonomi syariah lainnya. Pengertian dari "antara orang-orang yang beragama Islam" adalah termasuk orang atau badan hukum yang dengan sendirinya menundukan diri dengan sukarela kepada hukum Islam mengenai hal-hal yang menjadi kewenangan Pengadilan Agama.

2. Pada Pasal 2 Undang-Undang Nomor 7 Tahun 1989 dinyatakan bahwa kewenangan Pengadilan Agama adalah mengenai perkara perdata tertentu. Artinya bahwa Pengadilan Agama hanyalah mengadili perkara antar perorangan saja. Dalam Undang-Undang Nomor 3 Tahun 2006 istilah "perkara perdata tertentu" dirubah menjadi "perkara tertentu" sehingga kompetensi Pengadilan Agama tidak hanya pada perkara perdata saja. Misalnya kewenangan Pengadilan Agama di Nangroe Aceh Darussalam yang memberlakukan hukum Islam sehingga sebagai badan peradilan khusus berwenang mengadili perkara perdata dan pidana.

3. Mengenai sengketa milik sebagaimana diatur dalam Pasal 50 UndangUndang Nomor 7 Tahun 1989 yang menyatakan bahwa "Dalam hal terjadi sengketa mengenai hak milik atau keperdataan lain dalam perkara-perkara sebagaimana dimaksud dalam pasal 49, maka khusus mengenai obyek yang 
menjadi sengketa tersebut harus diputus lebih dahulu oleh Pengadilan dalam lingkungan Peradilan Umum”. Pasal ini memerintahkan agar terhadap sebagian atau seluruh obyek perkara yang diajukan ke Pengadilan Agama yang dinyatakan oleh Tergugat dalam jawabannya di persidangan sebagai miliknya pribadi maka tanpa dilakukan pemeriksaan selanjutnya, Pengadilan Agama harus menyatakan obyek tersebut sebagai sengketa milik, oleh karena itu harus diselesaikan terlebih dahulu di Pengadilan Negeri.

Pengadilan Agama tidak dapat terus melakukan pemeriksaan terhadap obyek perkara yang dinyatakan sebagai sengketa hak milik tersebut sebagaimana Pasal 50 yang menyatakan "penyelesaian objek yang menjadi sengketa dimaksud tidak berarti menghentikan proses peradilan di Pengadilan Agama atas objek yang tidak menjadi sengketa”. Dari ini pasal tersebut nampak jelas bahwa Pengadilan Agama dapat terus memeriksa dan mengadili sengketa yang tidak terkait dengan sengketa hak milik. Sebaliknya apabila objek dinyatakan sebagai sengketa hak milik maka harus dikeluarkan dari pemeriksaan perkara pada Pengadilan Agama dan terlebih dahulu diajukan ke Pengadilan Negeri untuk memperoleh suatu putusan tentang status objek tersebut (aanhanging).

Namun dengan diundangkannya Undang-Undang Nomor 3 Tahun 2006, Undang-Undang telah memberikan kebijakan yang sangat simple dan praktis sehingga penyelesaian suatu perkara yang di dalamnya terdapat objek yang terkait dengan sengketa hak milik atau keperdataan lain, dapat diselesaikan bersama-sama dengan objek yang tidak terkait dengan sengketa hak milik, tanpa terlebih dahulu menunggu pemeriksaan dari Pengadilan Negeri tentang status objek perkara. Hal ini diatur dalam Pasal 50 ayat (2) Undang-Undang Nomor 3 Tahun 2006 yang menyatakan "Apabila terjadi sengketa hak milik sebagaimana dimaksud pada ayat (1) yang subyek hukumnya antara orang-orang yang beragama Islam, objek sengketa tersebut diputus oleh Pengadilan Agama bersama-sama perkara sebagaimana dimaksud dalam Pasal 49".

Pasal 50 ayat (1) tersebut memerintahkan Pengadilan Agama meneruskan pemeriksaan terhadap objek perkara meskipun ada bantahan tergugat bahwa sebagian atau seluruh objek perkara masih terkait dengan hak milik. Hakim melalui pemeriksaan di persidangan pada tahap pembuktian akan menilai apakah benar objek perkara yang terkait sengketa hak milik. Apabila terbukti maka Pengadilan Agama di dalam diktum putusannya harus menyatakan tidak dapat diterima (neit ont vanklijke verklaard).

4. Selain perubahan atas kewenangan perkara juga mengalami perubahan dalam hak opsi khususnya dalam bidang hukum waris. Dalam Undang-Undang Nomor 7 Tahun 1989 bagi orang Islam yang berperkara kewarisan masih dapat memilih apakah akan menyelesaikan di Pengadilan Agama dengan 
menerapkan hukum Islam atau akan menerapkan hukum waris adat/KUH Perdata yang merupakan kewenangan Pengadilan Negeri. Dengan adanya Undang-Undang Peradilan Agama maka hak opsi tersebut dicabut sehingga apabila antara orang Islam ingin mengajukan perkara waris ke pengadilan maka otomatis akan menjadi kewenangan dari Pengadilan Agama. Dengan demikian maka kewenangan yang diberikan Undang-Undang Nomor 3 Tahun 2006 eksistensi Pengadilan Agama semakin maju dan kokoh di dalam mengadili dan memutus perkara sengketa waris bagi pencari keadilan yang beragama Islam.

Dalam pasal 49 Undang-Undang Nomor 7 Tahun 1989 sebenarnya telah ditegaskan bahwa perkara kewarisan antar orang yang beragama Islam merupakan kewenangan dari Pengadilan Agama. Dari Penjelasan Umum Undang-Undang tersebut masih membuka adanya opsi hukum kewarisan. Sebenarnya bidang kewarisan merupakan kewenangan mutlak Pengadilan Agama, namun mengingat kenyataan setelah tahun 1937 yaitu "tahun ditariknya kewenangan Peradilan Agama dan memindahkannya ke Pengadilan Negeri menimbulkan dualisme kesadaran hukum." Dalam pembahasan RUU Peradilan Agama di DPR, pemerintah dan DPR sepakat untuk menghilangkan pertentangan antara hukum Islam dan hukum adat. Hasil dari kesepakatan tersebut maka opsi hukum harus terjadi di luar pengadilan (sebelum berperkara).

Namun dengan adanya perubahan kewenangan tersebut di atas nampak jelas bahwa semua perkara waris Islam mutlak menjadi kewenangan dari Pengadilan Agama. Konsekwensi logisnya bahwa semua perkara yang berkait dengan kewarisan Islam yaitu tentang penentuan ahli waris, penentuan peninggalan (tirkah), penentuan bagian masing-masing ahli waris serta pelaksanaan pembagian harta peninggalan, mutlak menjadi kewenangan Pengadilan Agama. Realitanya walaupun Undang-Undang telah menyatakan bahwa Pengadilan Agama merupakan pengadilan satu-satunya yang berwenang menyelesaikan perkara kewarisan Islam, namun dalam kenyataannya sebagian masyarakat masih mengajukan perkara kewarisannya ke Pengadilan Negeri, yang notabene nantinya tidak menerapkan hukum waris Islam.

Perbedaan pendapat tentang berwenang tidaknya Pengadilan Negeri dalam perkara kewarisan orang Islam pasca berlakunya Undang-Undang Nomor 3 Tahun 2006, dapat ditinjau dari pendekatan asas hukum, teori hukum ataupun hukum formil. Asas hukum yang dapat digunakan adalah lex specialis derogat legi generali. Asas ini menyatakan bahwa hukum yang bersifat khusus mengalahkan hukum yang bersifat umum. Dengan asas tersebut maka

\footnotetext{
${ }^{2}$ Busthanul Arifin, Pelembagaan Hukum Islam di Indonesia, Gema Insani Press, Jakarta, 1996, 100.
} 
Pengadilan Negeri dikategorikan sebagai peradilan yang bersifat umum dan Pengadilan Agama merupakan pengadilan yang bersifat khusus.

Ditinjau dari asas hukum, penyelesaian konflik kewenangan mengadili perkara warisan orang Islam, Pengadilan Agama merupakan pengadilan yang bersifat khusus. Undang-Undang Peradilan Agama adalah undang-undang yang bersifat khusus karena memang khusus diperuntukan bagi orang yang beragama Islam. Sebaliknya Pengadilan Negeri disediakan bagi semua jenis perkara pidana dan perdata dengan mengindahkan agama para pencari keadilan. Dengan asas hukum tersebut maka Pengadilan Agama menyisihkan kewenangan Pengadilan Negeri dalam perkara kewarisan.

Berdasarkan sifatnya, hukum dapat digolongkan dalam hukum imperatif dan hukum fakultatif. Hukum imperatif adalah hukum yang memaksa dan secara a priori harus ditaati, sedangkan hukum fakultatif adalah hukum yang tidak harus mengikat atau dapat dipilih. Dari sisi pendekatan hukum formil, Sudikno Mertokusumo menyatakan bahwa hukum acara bukanlah merupakan hukum pelengkap dari hukum materiil melainkan keduanya merupakan dua hal yang tidak dapat dipisahkan. Tidak mungkin hukum perdata materiil berdiri sendiri lepas sama sekali dari hukum perdata materiil. Tidak ada gunanya ada hukum perdata materiil apabila tidak dapat dilaksanakan atau direalisir dan untuk realisasinya itu diperlukan hukum acara perdata. Sebaliknya hukum acara perdata sebagai upaya untuk menjamin dilaksanakannya hukum perdata materiil. Akan tetapi hukum perdata materiil tidak mungkin ditegakan tanpa hukum acara perdata. Hukum perdata materiil hanya dapat dipertahankan dan ditegakan melalui peradilan dalam hukum acara perdata. ${ }^{3}$

Pembagian waris yang sudah menjadi sengketa dan harus diajukan ke pengadilan maka hal tersebut termasuk dalam hukum formil. Star Busmann menyatakan bahwa "hukum acara perdata pada asasnya bersifat mengikat. ${ }^{4}$ Kekuatan mengikat suatu ketentuan hukum formil telah ditentukan oleh pembuat Undang-Undang. Dengan demikian kedudukan Peradilan Agama sebagai institusi penegak hukum dalam negara hukum Republik Indonesia haruslah memiliki status dan kedudukan yang kuat. Kuatnya status dan kedudukan Peradilan Agama akan memberikan kepastian hukum bagi pencari keadilan, termasuk dalam mengadili perkara kewarisan orang Islam.

\footnotetext{
${ }^{3}$ Sudikno Mertokusumo, Hukum Acara Perdata Indonesia, Yogyakarta, Liberty, 1985, hlm. 5

${ }^{4}$ Starr Busman, Mr. C.M. Hoofstukken van Burgerlijke Rechtvoeredering, Harleem, de Erven F Bohn, 1984, pp 18 dalam Sudikno Mertokusumo, Hukum Acara Perdata Indonesia, Yogyakarta, Liberty, 1985, hlm. 6
} 


\section{Peranan Advokat Dalam Mewujudkan Kewenangan Pengadilan Agama Dalam Bidang Kewarisan}

Undang-Undang Dasar 1945 menyatakan secara tegas bahwa negara Indonesia adalah negara hukum. Prinsip negara hukum menuntut antara lain jaminan kesederajatan bagi setiap orang di hadapan hukum (equality before the law). Oleh karena itu Undang-Undang Dasar juga menentukan bahwa setiap orang yang berhak atas pengakuan, jaminan, perlindungan dan kepastian hukum yang adil serta pengakuan yang sama di hadapan hukum. Dalam usaha mewujudkan prinsip-prinsip negara hukum dalam kehidupan bermasyarakat dan bernegara, peran dan fungsi advokat sebagai profesi yang bebas, mandiri dan bertanggung jawab merupakan hal penting, disamping lembaga peradilan dan instansi penegak hukum lainnya seperti kepolisian dan kejaksaan. Peranan advokat sebagai penegak hukum mempunyai kedudukan yang setara dengan penegak hukum yang lain. ${ }^{5}$

Melalui jasa hukum yang diberikan, advokat menjalankan tugas profesinya demi tegaknya keadilan berdasarkan hukum untuk kepentingan masyarakat pencari keadilan, termasuk usaha memberdayakan masyarakat dalam menyadari hak-hak fundamental di depan hukum. Advokat sebagai salah satu unsur sisem peradilan merupakan salah satu pilar dalam menegakkan supremasi hukum dan hak asasi manusia. Selain dalam proses peradilan, peran advokat juga dibutuhkan di luar jalur profesi peradilan. Kebutuhan jasa hukum advokat di luar proses peradilan pada saat ini semakin meningkat sejalan dengan berkembangnya kebutuhan hukum masyarakat terutama dalam memasuki kehidupan yang semakin terbuka dalam pergaulan antar bangsa.

Dalam suatu negara hukum, kehadiran advokat bukan hanya sematamata membela hak-hak dari terdakwa (dalam hukum pidana) tetapi lebih pada peradilan yang adil. Advokat sering juga disebut sebagai pengacara, lanyer ataupun pokrol. Advokat adalah profesi yang bebas, mandiri dan bertanggung jawab dalam menegakan hukum dan dalam melaksanakan profesinya dilindungi oleh undang-undang. Undang-undang advokat mengartikan advokat sebagai orang yang berprofesi memberi jasa hukum, baik di dalam maupun di luar pengadilan yang memenuhi persyaratan berdasarkan ketentuan undang-undang. Bentuk jasa hukum yang dapat diberikan oleh advokat berupa konsultasi hukum, bantuan hukum, menjalankan kuasa, mewakili, mendampingi, membela dan melakukan tindakan hukum lain untuk kepentingan hukum klien. Dari bentuk pelayanan di atas dapat disimpulkan bahwa jasa advokat adalah bersifat luas karena meliputi bidang ligitasi (proses di pengadilan) maupun non ligitasi (di luar pengadilan).

\footnotetext{
${ }^{5}$ Rosdalina, Peran Advokat Dalam Penegakan Hukum di Pengadilan Agama, Jurnal Politik Profetik, Volume 6 Nomor 2, 2015, 120.
} 
Undang-Undang Nomor 18 Tahun 2003 tentang Advokat disahkan pada tanggal 6 Maret 2003. Undang-Undang Advokat merupakan salah satu peraturan perundang-undangan yang lahir setelah amandemen Undang-Undang Dasar 1945. Berlakunya Undang-Undang Advokat merupakan perkembangan yang sangat positif dalam penegakan hukum di Indonesia. Berdasarkan UndangUndang Advokat, profesi advokat diakui eksistensinya sebagai salah satu penegak hukum disamping polisi, jaksa dan hakim. Sebenarnya cikal bakal profesi advokat secara formal telah diakui sejak jaman penjajahan Hindia Belanda yaitu sejak adanya Landraad. Landraad adalah lembaga peradilan untuk golongan pribumi berdasarkan Staatblad 1847 Nomor 23 yang diberlakukan pada 1 Mei 1848. ${ }^{6}$ Namun demikian pengakuan keberadaan profesi advokat tidak diatur secara khusus dan sistematis dalam aturan setingkat undang-undang melainkan hanya diatur secara sporadis pada pasal-pasal peraturan perundangudangan yang dikeluarkan oleh Pemerintah Hindia Belanda ataupun aturan setelah kemerdekaan misalnya pada masa Orde Lama maupun Orde Baru. Akibatnya profesi advokat sering dipandang sebelah mata oleh masyarakat dibandingkan dengan profesi penegak hukum yang lain.

Advokat merupakan salah satu elemen penting dalam penegakan hukum. Advokat yang menghubungkan kepentingan hukum masyarakat ketika berhadapan dengan negara. Menurut Jimly Asshiddiqie, "ketentuan Pasal 5 ayat (1) Undang-Undang Advokat memberikan status setara dengan penegak hukum lainnya dalam menegakkan hukum dan keadilan." " Secara umum dalam sistem kehakiman di Indonesia, hakim ditempatkan sebagai pihak yang mewakili kepentingan negara, jaksa dan kepolisian mewakili kepentingan pemerintah, sedangkan advokat menjaga dan mewakili kepentingan masyarakat. Dalam undang-undang advokat dijelaskan bahwa dalam usaha mewujudkan prinsipprinsip negara hukum dan kehidupan bermasyarakat dan bernegara, peran dan fungsi advokat sebagai profesi yang bebas, mandiri dan bertanggung jawab merupakan hal yang penting, disamping lembaga peradilan dan instansi penegak hukum misalnya kepolisian dan kejaksaan.

Melalui jasa hukum yang diberikan, advokat menjalankan profesinya demi tegaknya keadilan berdasarkan hukum untuk kepentingan masyarakat pencari keadilan termasuk memberdayakan masyarakat agar menyadari hak-hak fundamental mereka di depan hukum. Advokat sebagai salah satu unsur dari sistem peradilan merupakan salah satu pilar dalam menegakan supremasi hukum dan hak asasi manusia. Selain dalam proses peradilan, peran advokat juga terlihat di jalur profesi di luar pengadilan. Kebutuhan jasa hukum advokat di luar proses peradilan pada saat ini semakin meningkat, sejalan dengan semakin

\footnotetext{
${ }^{6}$ Kelik Pramudya, Panduan Praktis Menjadi Advokat, PT Buku Seru, Jakarta, 2011, 3.

${ }^{7}$ Jimly Asshiddiqie, Peran Advokat Dalam Penegakan Hukum, bahan Orasi Hukum pada Acara “pelantikan DPP IPHI Masa Bakti 2007-2012, Bandung, 19 Januari 2008.
} 
berkembangnya kebutuhan masyarakat terutama dalam kehidupan yang semakin terbuka dalam pergaulan antar bangsa. Melalui pemberian jasa konsultasi, negoisasi maupun dalam pembuatan kontrak-kontrak dagang, profesi advokat diharapkan memberi sumbangan bagi pemberdayaan masyarakat serta pembaharuan hukum, misalnya penyelesaian sengketa di luar pengadilan.

Dalam memperjuangkan kepentingan kliennya seorang advokat melaksanakan tugasnya menerima honorarium. Profesi advokat berbeda dengan seorang pebisnis yang mencari profit untuk mendapatkan keuntungan yang sebesar-besarnya dari usaha yang dijalankan. Ontologi profesi advokat adalah mengutamakan pemahaman bahwa profesi advokat dalam lingkup kegiatan etis yang bernilai adanya kedudukan profesi terhormat, adanya pemahaman keilmuan serta tindakan-tindakan yang dapat diukur secara moral. Hal yang penting dalam diri seorang advokat adalah independensi. ${ }^{8}$ Dengan independensi advokat dapat terlaksana sebagai implementasi dari profesionalisme advokat yang tidak cenderung melaksanakan tugas profesinya hanya karena dibayar klien. Hal ini disebabkan profesi advokat harus menjaga citra dan martabat kehormatan profesi serta setia dan menjunjung tinggi Kode Etik dan Sumpah Profesi, yang pelaksanaannya diawasi oleh Dewan kehormatan sebagai suatu lembaga yang eksistensinya telah dan harus diakui setiap advokat.

Sebagaimana telah dijelaskan sebelumnya bahwa advokat tidak lagi identik dengan pelayanan terhadap klien di persidangan atau suatu sengketa. Seorang klien baik perorangan maupun badan hukum atau lembaga lain biasanya menunjuk seorang advokat untuk mengurus segala sesuatu yang berkenaan dengan hukum, pada perkembangannya juga dapat mengurus perizinan yang ada sangkut pautnya dengan hukum.

Menurut Oemar Seno Adji, "peraturan-peraturan profesi pada umumnya mengandung hak-hak yang fundamental dan mempunyai peraturanperaturan mengenai tingkah laku atau perbuatan dalam melaksanakan profesi." Secara umum terdapat empat norma yang mempunyai peranan penting di dalam hukum yaitu:

1. Kemanusiaan

Norma kesusilaan berkait dengan penegakan hukum yaitu manusia senantiasa diperlakukan sebagai manusia. Dengan norma kesusilaan diharapkan seorang advokat memiliki keluhuran pribadi.

2. Keadilan

Keadilan merupakan salah satu tujuan dari hukum yaitu memberikan kepada orang lain sesuai dengan haknya. Keadilan bersifat relatif sehingga dalam

\footnotetext{
${ }^{8}$ Syafruddin Makmur, Peran Advokat Dalam Penegakan Hukum Ekonomi di Indonesia, Salam:Jurnal Filsafat dan Budaya Hukum, UIN Jakarta, 2017, 61.

${ }^{9}$ Oemar Seno Adji, Profesi Advokat, Penerbit Erlangga, Jakarta, 1991, 15.
} 
memberikan penilaian antara orang yang satu dengan orang yang lain akan suatu hal maka tidak tertutup kemungkinan akan mempunyai penilaian yang berbeda

3. Kepatutan

Kepatutan merupakan nilai-nilai di dalam masyarakat terhadap sesuatu hal yang dianggap baik dan layak. Untuk menentukan norma kepatutan ini penilaiannya tergantung pada masyarakat.

4. Kejujuran

Seluruh penegak hukum termasuk advokat harus bersikap jujur dalam mengurus atau menangani hukum dan memberikan pelayanan kepada masyarakat yang mencari keadilan. Salah satu realisasi dari norma kejujuran adalah menjauhkan diri dari perbuatan-perbuatan yang curang dalam mengurus perkara.

Selanjutnya Oemar Soeno Adji menyatakan bahwa advokat memiliki kewajiban-kewajiban yang membebani profesi advokat, yaitu:

1. Harus memiliki kepribadian yang takwa kepada Tuhan Yang Maha Esa dan dalam melaksanakan tugasnya harus menjunjung tinggi hukum berdasarkan Pancasila dan Undang-Undang Dasar 1945 serta sumpah jabatan, tidak diskriminatif dan sebagainya;

2. Tuntutan kewajiban yang berhubungan dengan klien antara lain dalam mengurus perkara mendahulukan kepentingan klien daripada kepentingan pribadi, tidak membebani klien dengan biaya-biaya yang tidak perlu, mengarahkan perkara klien sesuai dengan perundangundangan dan sebagainya;

3. Dalam hubungannya dengan teman sejawat, misalnya kewajiban untuk tidak menarik klien dari teman sejawat, menjelek-jelekkan teman sejawat untuk kepentingan pribadi dan sebagainya.

4. Dalam bertindak dan menangani perkara, advokat tidak diperkenankan menambah catatan-catatan pada berkas di dalam/di luar sidang meskipun hanya bersifat "ad informandum" dan tidak boleh menghubungi saksi-saksi lawan dalam perkara yang bersangkutan; ${ }^{10}$

Dengan berlakunya Undang-Undang Advokat tidak ada perbedaan antara pengacara dan advokat. Pada awalnya seorang advokat dapat beracara di seluruh wilayah Indonesia, sedangkan pengacara wilayahnya hanya sebatas propinsi dalam wilayah dimana bertugas dan berkedudukan.

Argumentasi tentang keharusan adanya advokat di dalam masyarakat timbul "karena di dalam masyarakat tidak banyak justisiable yang memiliki pengetahuan yang memadai tentang hukum sehingga dalam berperkara

\footnotetext{
${ }^{10}$ Oemar Seno Adji, Profesi Advokat, Penerbit Erlangga, Jakarta, 1991, ...15.
} 
meminta bantuan kepada advokat."11 Sebagian masyarakat yang lain memandang pengadilan sebagai suatu lembaga yang menakutkan atau anggapan bahwa berperkara pengadilan adalah proses yang berbelit-belit dan rumit sehingga sebagian masyarakat tersebut alergi ketika berhubungan dengan pengadilan. Dengan demikian dalam perkara perdata peranan advokat merupakan hal yang penting dalam rangka menjadi kuasa tergugat/penggugat/pemohon dalam persidangan di pengadilan.

Di samping sisi positif tersebut, terdapat peran advokat yang terkadang merugikan kepada pemberi kuasa ataupun kelancaran terhadap proses di pengadilan, yaitu antara lain:

1. Persetujuan tentang pemberian kuasa antara advokat dengan klien, yang tertuang dalam surat kuasa, batasannya tidak jelas sehingga terkadang advokat melakukan tindakan yang berlebihan. Pada umumnya ini terjadi karena klien tidak membaca ataupun memahami isi surat kuasa, yang merupakan tanda adanya kontrak antara advokat dengan klien.

2. Advokat merupakan wakil atau kuasa dari klien sehingga ada sebagian advokat yang kurang teliti mendengarkan paparan klien tentang duduk perkaranya sehingga tidak tertutup kemungkinan dalam menjalankan tugasnya memberikan keterangan yang salah dan atas kesalahan tersebut kan merugikan terhadap klien;

3. Dalam penggunaan jasa advokat di Pengadilan tidak selamanya jalannya perkara akan sesuai dengan prinsip sederhana, cepat dan biasa ringan. Terkadang advokat dengan sengaja membuat perkara berlarut-larut dan berkepanjangan. Atau selalu menganjurkan pada klien untuk melakukan upaya hukum ketika perkaranya kalah. Kedua hal tersebut yang menyebabkan terjadinya penumpukan perkara baik di tingkat banding ataupun kasasi.

Sebagaimana telah dijelaskan sebelumnya bahwa profesi advokat sangat berperan dalam proses sebelum ataupun ketika proses perkara di persidangan. Advokat adalah pihak yang mengarahkan penyelesaian perkara dan pada umumnya klien hanya menyetujui apa yang menjadi arahan dari advokat. Arahan ini sangat penting bagi kelanjutan perkara seorang klien, misalnya dalam menentukan suatu perkara akan diajukan ke pengadilan tertentu sesuai dengan keinginan dari advokat.

Berdasarkan hasil penelitian Afdol, tentang pemanfaatan Pengadilan Agama dalam mengadili perkara kewarisan antara orang Islam sangatlah dipengaruhi oleh tiga hal yaitu politik hukum, peraturan hukum dan kesadaran

${ }^{11}$ E. Sumaryono, Etika Profesi Hukum, Norma-Norma Bagi Penegak Hukum, Kanisius, Yogyakarta, 1995, 156. 
hukum. ${ }^{12}$ Berkait dengan profesi advokat dalam beracara di pengadilan maka kesadaran hukum advokat menentukan ke pengadilan manakah suatu perkara kewarisan akan diajukan.

Selama rentang tahun 1989-1995 (setelah berlakunya Undang-Undang Nomor 7 Tahun 1989 tentang Peradilan Agama), perkara kewarisan yang diperiksa di Pengadilan Negeri dan Pengadilan Agama mayoritas telah menggunakan jasa pengacara. Di Pengadilan Negeri Surabaya yang menggunakan jasa pengacara sebanyak 94 perkara sedangkan yang tidak menggunakan jasa pengacara sebanyak 19 perkara. Perkara kewarisan di Pengadilan Agama yang menggunakan jasa Pengacara pada kurun waktu yang sama sebanyak 22 perkara dan yang tidak menggunakan jasa pengacara hanya 3 perkara. Penggunaan jasa advokat di pengadilan yang lain, juga tidak jauh berbeda di Pengadilan Negeri dan Pengadilan Agama di Jember, Madiun, Malang, dan Pamekasan. Di lima kabupaten/kotamadya tersebut secara kuantitas masyarakat lebih banyak yang menggunakan kuasa pengacara dibandingkan dengan hadir sendiri ke pengadilan. ${ }^{13}$

Realita di atas menunjukan bahwa advokat sebagai kuasa/wakil. Dengan demikian peran advokat sangatlah besar dalam menentukan ke pengadilan mana perkara akan diajukan atau bergantung pada kemauan dari advokat. Dalam praktik tidak tertutup kemungkinan seorang advokat cenderung menghindari Pengadilan Agama dan mengajukan perkara kewarisan orang Islam ke Pengadilan Negeri.

Seorang advokat sebagai penegak hukum wajib memahami dan mengikuti segala perundang-undangan yang berlaku sehingga dalam menjalankan kuasanya juga harus mengikuti segala prosedur beracara di pengadilan termasuk memahami kewenangan Pengadilan Agama dalam perkara kewarisan setelah berlakunya Undang-Undang Nomor 3 Tahun 2006. Idealnya seorang advokat harus mengikuti ketentuan tentang kewenangan Pengadilan Agama tersebut dan bukan untuk menghindarinya sehingga lebih memilih mengajukan kewenangan perkara kewarisan ke Pengadilan Negeri dengan alasan perbuatan melawan hukum.

Dari sisi hukum acara mengajukan perkara kewarisan dengan dasar perbuatan melawan hukum menurut penulis merupakan tindakan yang sah-sah saja. Namun apabila dikaitkan dengan nilai keadilan dan kepatutan dari seorang advokat, hal tersebut tidak sesuai dengan keadilan karena dengan mengajukan

12 Afdol, Landasan Hukum Positif Pemberlakuan Hukum Islam dan Permasalahan Implementasi Hukum Kewarisan Islam, Airlangga University Press, Surabaya, 2003, 57.

${ }_{13}$ Afdol, Pilihan Hukum Masyarakat Berkaitan Dengan Kewenangan Pengadilan Agama Dalam Perkara Warisan Sebagai Dampak Pilihan Hukum, Disertasi, Program Doktor Ilmu Hukum Universitas Diponegoro, Semarang, 2002, 155. 
perkara waris ke Pengadilan Negeri berarti mengajukan ke pengadilan yang sebenarnya tidak berwenang. Konsekuensinya perkara tersebut pada tahap awal hakim Pengadilan Negeri akan menolak perkara dengan alasan bukan kewenangan absolut dari Pengadilan Negeri. Apabila ini terjadi berarti advokat harus memulai dari proses pendaftaran perkara lagi ke Pengadilan Agama sehingga tidak sesuai dengan asas sederhana, cepat dan biaya ringan. Tindakan advokat tersebut sudah merugikan klien baik dari sisi waktu dan biaya.

Pasal 58 dan 96 RV (Wetboek van Burgerlijk Rechtvordering) mengatur tentang tindakan advokat yang merugikan terhadap klien. Pasal 58 RV menyatakan bahwa "Para advokat dan pengacara yang dalam pelayananannya melampaui batas wewenang mereka dapat ditunjuk untuk membayar seluruh atau sebagian biaya, bahkan dapat dijatuhi hukuman ganti rugi apabila ada alasan-alasan untuk itu". Sedangkan Pasal 96 RV mengatur tentang biaya dari akte-akte proses perkara yang batal atau berkelebihan, yang dapat dituntut pada seorang advokat. Kedua pasal tersebut tidak diatur dalam Undang-Undang Advokat. Malahan dalam Pasal 16 dinyatakan bahwa advokat tidak dapat dituntut baik secara perdata ataupun pidana dalam menjalankan profesinya dengan itikat baik untuk kepentingan pembelaan klien dalam sidang pengadilan. Pasal 16 tersebut tidak dapat dijadikan sebagai dasar untuk menuntut ganti rugi kepada advokat yang telah melakukan kesalahan sehingga mengakibatkan kerugian kepada klien.

Masyarakat pengguna jasa advokat pada umumnya mereka yang tidak memiliki pengetahuan hukum yang memadai sehingga menggunakan kuasa dalam mempertahankan hak-haknya. Sebaliknya advokat secara umum telah memahami hukum baik hukum materiil maupun hukum acara. Dengan demikian apabila seorang advokat acuh tak acuh ataupun mengabaikan prosedur hukum yang seharusnya ditempuh maka berarti terdapat kesenjangan antara kepentingan klien dengan tindakan advokat. Idealnya advokat memberi perlindungan khusus pada klien termasuk dalam menjalankan kuasa yaitu dengan mengajukan perkara sesuai dengan kewenangan pengadilan.

\section{Penutup}

Dalam menjalankan fungsi dan peranannya sebagai kuasa dan disebut sebagai profesi yang mulia (officium nobile) maka seorang advokat harus menggunakan aturan perundang-undangan sehingga dalam mengajukan perkara kewarisan antar orang Islam harus mengajukan perkara sebagaimana kompetensi peradilan yakni Peradilan Agama dan tidak mengajukan perkara dengan dasar/alasan perbuatan melawan hukum yang notabene merupakan kewenangan Pengadilan Negeri. Pengajuan perkara kewarisan yang disamarkan sebagai perbuatan melawan hukum secara yuridis akan dibatalkan oleh Pengadilan Tinggi ataupun Mahkamah Agung, dengan putusan bahwa perkara tersebut merupakan kewenangan Pengadilan Agama. Apabila hal ini terjadi 
maka akan memberikan kerugian baik kepada pihak-pihak yang berperkara, pengadilan ataupun kepada perkembangan hukum.

\section{Daftar Bacaan}

Adji, Oemar Seno, Profesi Advokat, Penerbit Erlangga, Jakarta, 1991.

Afdol, Landasan Hukum Positif Pemberlakuan Hukum Islam dan Permasalahan Implementasi Hukum Kewarisan Islam, Airlangga University Press, Surabaya, 2003.

Afdol, Pilihan Hukum Masyarakat Berkaitan Dengan Kewenangan Pengadilan Agama Dalam Perkara Warisan Sebagai Dampak Pilihan Hukum, Disertasi, Program Doktor Ilmu Hukum Universitas Diponegoro, Semarang, 2002. Peradilan Agama di Indonesia Pasca UU No.3 Tabun 2006 (Sejarah, Kedudukan dan Kewenangan), UII Press, Yogyakarta, 2007.

Anshori, Abdul Ghofur, Peradilan Agama di Indonesia Pasca UU No.3 Tahun 2006 (Sejarah, Kedudukan dan Kewenangan), UII Press, Yogyakarta, 2007.

Arifin, Busthanul, Pelembagaan Hukum Islam di Indonesia, Gema Insani Press, Jakarta, 1996.

Asshiddiqie, Jimly, Peran Advokat Dalam Penegakan Hukum, bahan Orasi Hukum pada Acara "pelantikan DPP IPHI Masa Bakti 2007-2012, Bandung, 19 Januari 2008.

E. Sumaryono, Etika Profesi Hukum, Norma-Norma Bagi Penegak Hukum, Kanisius, Yogyakarta, 1995.

Makmur, Syafruddin, Peran Advokat Dalam Penegakan Hukum Ekonomi di Indonesia, Salam:Jurnal Filsafat dan Budaya Hukum, UIN Jakarta, 2017

Mertokusumo, Sudikno, Hukum Acara Perdata Indonesia, Yogyakarta, Liberty, 1985.

Pramudya, Kelik, Panduan Praktis Menjadi Advokat, PT Buku Seru, Jakarta, 2011.

Rosdalina, Peran Advokat Dalam Penegakan Hukum di Pengadilan Agama, Jurnal Politik Profetik, Volume 6 Nomor 2, 2015 
Star Busman, Mr. C.M. Hoofstukken van Burgerlijke Rechtvoeredering, Harleem, de Erven F Bohn, 1984, pp 18 dalam Sudikno Mertokusumo, Hukum Acara Perdata Indonesia, Yogyakarta, Liberty, 1985. 